Grenek: Jurnal Seni Musik Vol. 10 No. 1 (Juni 2021) Page: 82-92

Prodi Pendidikan Musik FBS Unimed

p- ISSN 2301-5349

e- ISSN 2579-8200

\title{
KOMPARASI UNSUR MUSIK DAN INTRODUKSI LAGU YAMKO RAMBE YAMKO ARANSEMEN AGUSTINUS BAMBANG JUSAN DENGAN BUDI SUSANTO YOHANES
}

\author{
Zul Hazmi Harahap ${ }^{1}$, Theodora Sinaga ${ }^{2}$ \\ Program Studi Pendidikan Musik, Fakultas Bahasa dan Seni \\ Universitas Negeri Medan Jalan Willem Iskandar Pasar V Medan Estate \\ 20221,Sumatera Utara-Indonesia \\ Email:1Zulhazmiharahap98@gmail.com
}

\begin{abstract}
Abstrak
Penelitian ini bertujuan untuk mengetahui (1) Komparasi unsur musik lagu Yamko Rambe Yamko aransemen Agustinus Bambang Jusana Dengan Budi Susanto Yohanes (2) Komparasi introduksi lagu Yamko Rambe Yamko aransemen Agustinus Bambang Jusana Dengan Budi Susanto Yohanes. Teori yang digunakan dalam penelitian ini yaitu teori komparasi, aransemen, unsur musik, dan introduksi. Hasil penelitian ini menunjukkan bahwa (1) Kedua aransemen memiliki perbedaan pada unsur musiknya, aransemen Agustius Bambang Jusana terdiri dari 80 birama, dengan nada dasar F=Do, tempo Allegro = $130 \mathrm{MM}$, tidak terdapat perubahan birama dan tidak terlalu banyak perubahan dinamika, sedangkan aransemen Budi Susanto Yohanes terdiri dari 94 birama, nada dasar E=Do, tempo vivace $=112 \mathrm{MM}$, terdapat perubahan birama diantaranya, 4/4, 3/4, dan 6/4. Melodi, ritme dan harmoni dari kedua aransemen pada bagian tema umumnya sama tetapi terdapat beberapa perbedaan variasi pada kedua aransemen, (2) Bagian introduksi dari kedua aransemen memilki perbedaan pada aransemen Agustinus Bambang Jusana, bagian introduksi didominasi oleh vokal tradisi teriakan peperangan khas masyarakat papua sedangkan aransemen Budi Susanto Yohanes bagian introduksi cenderung lebih singkat dan didominasi oleh penggunaan harmonisasi yang bervariatif yang disusun secara kanon / bersahutan dari setiap posisi suara.
\end{abstract}

Kata Kunci : Komparasi, Aransemen, Yamko Rambe Yamko, unsur musik, introduksi.

\begin{abstract}
This study aims to determine (1) Comparison of the musical elements of the song Yamko Rambe Yamko arranged by Agustinus Bambang Jusana and Budi Susanto Yohanes (2) Comparison of the introduction of the song Yamko Rambe Yamko arranged by Agustinus Bambang Jusana and Budi Susanto Yohanes. The theory used in this research is the theory of comparison, arrangement, elements of music, and production. The selection of population and sample in this study is using the total sampling technique, where the number of population is the same as the sample, while the sample is a sheet document of the song sheet Yamko Rambe Yamko arranged by Agustinus Bambang Jusana and Budi Susanto Yohanes. Data collection techniques used observation techniques, interview techniques, documentation, and laboratory work. The data analysis technique used is descriptive qualitative analysis technique. This research was conducted at the Sendratasik Laboratory, Faculty of Language and Arts, Medan State University. The results of this study indicate that (1) the two arrangements have differences in their musical elements, Agustius Bambang Jusana's arrangement consists of 80 bars, with the basic tone of $F=D o$, tempo of Allegro $=130 \mathrm{MM}$, there is no change in time and there are not too many changes in dynamics, whereas Budi Susanto Yohanes' arrangement consists of 94 bars, the basic tone of $E=D o$, tempo vivace $=112 \mathrm{MM}$, there are changes in the bar, 4/4, 3/4, and 6/4. The melody, rhythm and harmony of the two arrangements in the theme section are generally the same but there are several different variations in the two arrangements, (2) The introductory part of the two arrangements has differences in Agustinus Bambang Jusana's arrangement, the introductory part is dominated by the vocals of the battle cry tradition typical of the Papuan people while Budi Susanto Yohanes' arrangements in the introduction part tend to be shorter and dominated by the use of varied harmonizations which are arranged canonically from each sound position.
\end{abstract}

Keywords: Comparison, Arrangement, Yamko Rambe Yamko, musical elements, introduction. 
Grenek: Jurnal Seni Musik Vol. 10 No. 1 (Juni 2021) Page: 82-92

Prodi Pendidikan Musik FBS Unimed

p- ISSN 2301-5349

e- ISSN 2579-8200

\section{PENDAHULUAN}

Karya musik murni merupakan karya musik yang seluruh komposisi musiknya meliputi unsur musik, struktur musik dan bentuk musiknya diciptakan asli berdasarkan ide dan kreatifitas pencipta, sedangkan karya musik aransemen merupakan sebuah karya musik yang diciptakan dengan melakukan gubahan terhadap komposisi asli dari sebuah karya musik atau lagu yang sudah ada tetapi tidak menghilangkan melodi aslinya. Karya musik aransemen diciptakan untuk membuat variasi baru pada sebuah lagu yang sudah ada, bahkan sebuah karya lagu yang berjudul sama bisa diaransemen oleh beberapa arranger, maka tidak bisa dipungkiri bahwa akan ditemukan perbedaan pada setiap karya aransemen, baik dari komposisi unsur musik, struktur musik, dan bentuk musiknya.

Unsur musik terdiri dari melodi, ritme / irama, tempo, harmoni, syair dan dinamika. McFarlane (2020:2) dalam jurnalnya mengakatakan Musical elements include, yet are not limited to pitch, volume/dynamic, tempo, rhythm, and melody artinya elemen musik termasuk, dan tidak terbatas hanya pada nada, volume/dinamika, tempo, ritme, dan melodi. Selain itu Isbah dkk (2019:50) dalam jurnalnya juga mengatakan bahwa struktur itu antara lain : introduksi, chorus, interlude, variasi, ending dan vamp. Setiap karya aransemen pasti memiliki komposisi musik yang berbeda, hal ini dikarenakan setiap arranger memiliki latar belakang, tujuan, kebutuhan, kreatifitas, musikalitas, dan pengalaman yang berbeda sehingga setiap karya aransemen akan memiliki perbedaan walaupun lagu yang diaransemen berjudul sama. Setiap karya aransemen lagu yang sama tentu saja bisa dinikmati dan dimainkan oleh setiap orang namun tidak setiap orang dapat mengetahui secara rinci bagaimana perbedaan komposisi musik pada setiap karya aransemen. Sama halnya dengan observasi awal peneliti sebagai seorang anggota paduan suara.

Berdasarkan observasi awal peneliti sebagai seorang anggota paduan suara, peneliti sering menyaksikan banyak sekali kelompok paduan suara yang membawakan sebuah lagu yang berjudul sama tetapi memiliki aransemen yang berbeda. Hal ini juga bisa ditemukan dan disaksikan di media sosial seperti youtube dimana terdapat beberapa rekaman video kelompok paduan suara yang membawakan lagu yang berjudul sama tetapi dengan aransemen yang berbeda, salah satunya yaitu lagu Yamko Rambe Yamko. Peneliti memilih lagu Yamko Rambe Yamko dikarenakan lagu ini merupakan salah satu lagu daerah yang sangat populer di Indonesia, lagu ini identik dengan masyarakat Papua namun sebenarnya lagu ini bukan asli berasal dari Papua, hal ini dikutip dari https://www.bbc.com/indonesia/indonesia-53285500 yang memaparkan bahwa lagu Yamko Rambe Yamko adalah lagu yang dimodifikasi dari lagu Afrika. Lagu ini pertama kali dibawakan oleh Corry Rumbino yang merupakan seorang penyanyi Papua di istana negara saat peringatan hari kemerdekaan 17 Agustus pada awal tahun 1960-an. Lagu ini diklaim oleh tokoh seniman Papua sebagai bukan lagu dari daerah Papua, sebab lirik lagu tersebut bukan berasal dari Papua. lirik lagunya menceritakan tentang peperangan dalam sebelum hari kemerdekaan Indonesia, lagunya terdengar riang, penuh semangat, gembira, dan penuh hiburan tetapi sebenarnya lagu ini menggambarkan kesedihan. 
Grenek: Jurnal Seni Musik Vol. 10 No. 1 (Juni 2021) Page: 82-92

Prodi Pendidikan Musik FBS Unimed

p- ISSN 2301-5349

e- ISSN 2579-8200

Agustinus Bambang Jusana dan Budi Susanto Yohanes sama-sama mengaransemen lagu Yamko Rambe Yamko kedalam format paduan suara, namun berdasarkan observasi awal peneliti, kedua aransmen tersebut memiliki perbedaan yang kontras, dimana perbedaan sudah dapat dikenali walaupun hanya sekedar mendengar bagian awal dari lagu atau pada bagian introduksi saja. Selain itu aransemen lagu Yamko Rambe Yamko dari kedua arranger tersebut memungkinkan memiliki perbedaan baik dari komposisi unsur musiknya seperti melodi, ritme / irama, birama, tempo, nada dasar, harmoni, syair dan dinamikaserta memiliki karakteristik masing-masing yang menarik untuk didalami bagaimana perbandingannya.

Hal inilah yang membuat peneliti tertarik untuk melakukan penelitian komparasi terhadap unsur musik dan introduksi lagu Yamko Rambe Yamko aransemen Agustinus Bambang Jusana dengan Budi Susanto Yohanes.

\section{METODE PENELITIAN}

Untuk mencapai tujuan penelitian yang diinginkan, peneliti menggunakan metode penelitian kualitatif. Sesuai dengan judul penelitian serta masalah penelitian, maka peneliti menggunakan metode deksriptif kualitatif, yaitu untuk mengetahui bagaimana komparasi unsur musik dan introduksi lagu Yamko Rambe Yamko aransemen Agustinus Bambang Jusana dengan Budi Susanto Yohanes.

\section{HASIL DANPEMBAHASAN}

Lagu Yamko Rambe Yamko

Lagu Yamko Rambe Yamko merupakan salah satu lagu daerah yang sangat populer di Indonesia, lagu ini identik dengan masyarakat Papua namun sebenarnya lagu ini bukan asli berasal dari Papua, dikutip dari https://www.bbc.com/indonesia/indonesia-53285500 (online, diakses pada 15 desember 2020) memaparkan bahwa lagu Yamko Rambe Yamko adalah lagu yang dimodifikasi dari lagu Afrika.Lagu ini pertama kali dibawakan oleh Corry Rumbino yang merupakan seorang penyanyi Papua di istana negara saat peringatan hari kemerdekaan 17 Agustus pada awal tahun 1960-an. Lagu ini diklaim oleh tokoh seniman Papua sebagai bukan lagu dari daerah Papua, sebab lirik lagu tersebut bukan berasal dari Papua. Terlepas dari asal usulnya yang samar, lagu Yamko Rambe Yamko senantiasa dilekatkan dengan masyarakat Papua dan dinilai sebagai representasi identitas Papua dan diklaim sebagai lagu daerah Papua.

\section{Lagu Yamko Rambe Yamko Aransemen Agustinus Bambang Jusana.}

Agustinus Bambang Jusana mengaransemen lagu Yamko Rambe Yamko dalam format paduan suara dengan komposisi suara Sopran, Alto, Tenor dan Bass menggunakan notasi barat yaitu pada tahun 2000. Aransemen ini pertama kali dibawakan oleh Paduan Suara Mahasiswa UNPAR pada ajang First Choir Olympics di kota Linz Austria. Lagu Yamko Rambe Yamko aransemen Agustinus Bambang jusana terdiri dari 80 bar dan tediri dari empat bagian. 
Grenek: Jurnal Seni Musik Vol. 10 No. 1 (Juni 2021) Page: 82-92

Prodi Pendidikan Musik FBS Unimed

p- ISSN 2301-5349

e- ISSN 2579-8200

Bagian pertama lagu Yamko Rambe Yamko aransemen Agustinus Bambang Jusana merupakan bagian Introduksi atau bagian pembuka pada aransemen tersebut yang terdiri dari 35 bar yang dimulai dari bar 1 sampai dengan bar 35. Bagian kedua aransmen lagu ini merupakan tema lagu yang terdiri dari 24 bar yang dimulai dari bar 36 sampai dengan bar 60. Bagian kedua lagu ini menggunakan lirik lagu asli lagu Yamko Rambe Yamko. Bagian ketiga lagu merupakan bagian variasi atau pengembangan dari lagu Yamko Rambe Yamko yang terdiri dari 6 bar yang dimulai dari bar 61 sampai dengan bar 66, kemudian dilanjutkan pada bagian frase variasi kedua yang teridiri dari 4 bar, yang dimulai dari bar 71 sampai dengan bar 74 . Kemudian dilanjutkan pada bagian ke-4 yang merupakan bagian penutup lagu. Bagian ini terdiri 6 bar yang dimulai dari bar 75 sampai dengan bar 80 .

\section{Lagu Yamko Rambe Yamko Aransemen Budi Susanto Yohanes.}

Budi Susanto Yohanes mengaransemen lagu Yamko Rambe Yamko dalam format paduan suara dengan komposisi suara Sopran, Alto, Tenor, dan Bass yaitu pada bulan November tahun 2018. Aransemen ini diciptakan khusus sebagai lagu wajib kategori mahasiswa dan umum pada 13th National Folklore Festival 2019 -FEB UI..Lagu Yamko Rambe Yamko aransemen Budi Susanto Yohanes ini terdiri dari 94 bar dan secara garis besar terdiri dari empat bagian.

Bagian pertama lagu Yamko Rambe Yamko aransemen Budi Susanto Yohanes merupakan bagian Introduksi atau bagian pembuka yang terdiri dari 12 bar yang dimulai dari bar 1 sampai dengan bar 12. Bagian kedua aransemen lagu ini merupakan tema lagu yang terdiri dari 31 bar. Bagian tema lagu pada aransemen ini dibagi atas 3 bagian, yakni bagian A, jembatan dan bagian C. Adapun tema lagu bagian pertama terdiri dari 8 bar yang dimulai dari bar 13 sampai dengan bar 20. Kemudian dilanjutkan dengan jembatan menuju bagian tema lagu berikutnya yang terdiri dari 8 bar yang dimulai dari bar 21 sampai dengan bar 27.Kemudian tema lagu bagian ketiga terdiri dari 16 bar yang dimulai dari bar 29 sampai dengan bar 44. Tema lagu Yamko Rambe Yamko aransemen Budi Susanto Yohanes menggunakan lirik asli dari lagu Yamko Rambe Yamko. Setelah bagian Tema lagu, kemudian dilanjutkan dengan bagian variasi.

Bagian variasi pada aransemen ini terdiri dari 18 bar, yang dimulai dari bar 45 sampai dengan bar 62, adapun bagian variasi ini terdiri dari 2 bagian, bagian pertama dimulai dari bar 45 sampai dengan bar 54, dilanjutkan variasi bagian dua dimulai dari bar 55 sampai dengan bar 62. Kemudian dilanjutkan ke bagian pengulangan jembatan dan pengulangan tema lagu bagian A dan bagian C. setelah itu diakhiri dengan bagian penutup lagu, yang terdiri dari bar 9 dimulai dari bar 86 sampai dengan bar 94 . 
Grenek: Jurnal Seni Musik Vol. 10 No. 1 (Juni 2021) Page: 82-92

Prodi Pendidikan Musik FBS Unimed

p- ISSN 2301-5349

e- ISSN 2579-8200

\section{Komparasi Unsur Musik}

Tabel 1. Komparasi Unsur Musik 1 Bagian Awal (Introduksi)

\begin{tabular}{|c|c|c|c|}
\hline No. & $\begin{array}{l}\text { Indikator } \\
\text { Komparasi } \\
\text { Unsur } \\
\text { Musik }\end{array}$ & Aransemen Agustinus Bambang Jusana & $\begin{array}{c}\text { Aransemen Budi Susanto } \\
\text { Yohanes }\end{array}$ \\
\hline 1. & $\begin{array}{l}\text { Nada dasar } \\
\text { dan Tangga } \\
\text { nada }\end{array}$ & F Mayor & E Mayor \\
\hline 2. & Birama & $4 / 4$ & $4 / 4$ \\
\hline 3. & Tempo & Allegro $=130 \mathrm{MM}$ (cepat) & Vivace $=112 \mathrm{MM}$ (lincah) \\
\hline 4. & Jumlah Bar & 35 bar & $12 \mathrm{Bar}$ \\
\hline 5. & Dinamika & $\begin{array}{l}\text { terdapat sedikit perubahan dinamika, bar } 1 \\
\text { - } 10 \boldsymbol{f} \text {, bar } 11 \boldsymbol{f p} \text {, bar } 12 \text { - } 35 \text { kembalif. }\end{array}$ & $\begin{array}{l}\text { banyak terdapat perubahan } \\
\text { dinamika, bar } 1 \text { mf, bar } 2 \text { sub } \\
\boldsymbol{p} \text {, bar } 3 \boldsymbol{m f} \text { bar } 4 \text { cresccendo } f \text {, } \\
\text { bar } 5-9 \boldsymbol{p} \text {, bar } 10 \text { crescendo } \\
\text { dan bar } 12 \text { cresscendo } f \text {. }\end{array}$ \\
\hline 6. & $\begin{array}{l}\text { Melodi, } \\
\text { Ritme dan } \\
\text { Lirik. }\end{array}$ & $\begin{array}{l}\text { pada bar } 1 \text { - } 3 \text { diawali dengan Unisono dari } \\
\text { komposisi suara SATB dengan melodi "do } \\
\text { sol la sol dengan ritme not } 1 / 2 \text {, dan } \\
\text { dilanjutkan mi mi re do re do do" dengan } \\
\text { ritme not } 1 / 8 \text { dan } 1 / 16 \text { ditutup dengan } \\
\text { fermata yang didominasi dengan lirik E, O, } \\
\text { dan A. } \\
\text { Bar } 10 \text { - } 32 \text { melodi dibawakan oleh solo } \\
\text { tenor yang diikuti oleh SATB. Pada bar } 33- \\
35 \text { tenor sebagai solo yell (sorakan khas } \\
\text { masyarakat Papua dengan teknik mouth } \\
\text { patting / menepuk mulut sambil bersorak) } \\
\text { yang diikuti oleh posisi suara lainnya yang } \\
\text { ditutup dengan teriakan "hey!" }\end{array}$ & $\begin{array}{l}\text { Pada bar } 1-4 \text { melodi } \\
\text { dibawakan oleh tenor: "do do la } \\
\text { sol sol", bass } 1: \text { "mi mi re mi mi } \\
\text { mi" dan bass } 2 \text { : " do do do do } \\
\text { do". dengan ritme not } 1 / 8 \\
\text { dengan titik dan not } 1 / 16 \text { dengan } \\
\text { lirik "hey yamko rambe" yang } \\
\text { diulang-ulang. Pada bar } 4-5 \\
\text { sopran dan alto membawa } \\
\text { melodi yang sama kemudian } \\
\text { disambut tenor pada bar } 7 \text {, } \\
\text { kemudian bass pada bar } 9 \text { dan } \\
\text { diakhir dengan teriakan "he" } \\
\text { pada bar } 12 \text { sebagai penutup. }\end{array}$ \\
\hline 7. & Harmoni & $\begin{array}{l}\text { Harmoni yang cenderung sederhana, dimana } \\
\text { didominasi oleh akord pokok dimana pada } \\
\text { bar } 1-3 \text { diawali dengan akord I ( F Mayor), } \\
\text { bar } 3-5 \text { akord II M (G Mayor), bar } 6-11 \\
\text { kembali ke akord tingkat I. bar } 13 \\
\text { membentuk harmoni vertikal akord tingkat } \\
\text { I. bar } 14 \text { - } 32 \text { didominasi dengan harmoni } \\
\text { dengan akord tingkat } 1 \text { secara horizontal hal } \\
\text { ini dikarenakan banyaknya bagian solo tenor } \\
\text { yang diikuti oleh posisi suara lain. }\end{array}$ & $\begin{array}{l}\text { Banyak terdapat harmoni baru } \\
\text { yang terbentuk secara vertikal } \\
\text { dengan komposisi akord yang } \\
\text { bervariasi, dimana bar } 1-3 \\
\text { membentuk akord I (E Mayor), } \\
\text { bar } 4 \text { tingkat Vsus9 (BSus9), } \\
\text { bar } 5-11 \text { akord Asus9, dan bar } \\
12 \text { ditutup dengan akord } \\
\text { Bsus9,11. }\end{array}$ \\
\hline
\end{tabular}


Grenek: Jurnal Seni Musik Vol. 10 No. 1 (Juni 2021) Page: 82-92

Prodi Pendidikan Musik FBS Unimed

p- ISSN 2301-5349

e- ISSN 2579-8200

Tabel 2. Komparasi Bagian Tema Lagu Pertama.

\begin{tabular}{|c|c|c|c|}
\hline No & $\begin{array}{c}\text { Indikator } \\
\text { Komparasi } \\
\text { Unsur Musik }\end{array}$ & $\begin{array}{c}\text { Aransemen Agustinus Bambang } \\
\text { Jusana }\end{array}$ & $\begin{array}{c}\text { Aransemen Budi Susanto } \\
\text { Yohanes }\end{array}$ \\
\hline 1. & Jumlah Bar & $\begin{array}{l}\text { Terdiri dari } 25 \text { bar dimulai dari bar } 25- \\
36 \text {. }\end{array}$ & $\begin{array}{l}\text { Terdiri dari } 33 \text { bar dimulai dari } \\
\text { bar } 13-44\end{array}$ \\
\hline 2. & Dinamika & Forte & $\begin{array}{l}\text { Fortepada bagian tema lagu, dan } \\
\text { perubahan dinamika pada bar } 26 \\
\boldsymbol{p} \text {, dan kembali } \boldsymbol{f} \text { pada bar } 28 .\end{array}$ \\
\hline 3. & $\begin{array}{l}\text { Melodi, } \\
\text { dan Lirik. }\end{array}$ & $\begin{array}{l}\text { Melodi tema lagu pertama unisono } \\
\text { dibawakan oleh SATB dengan Melodi } \\
\text { "do sol sol la mi sol la, sol sol la re, mi do". } \\
\text { dengan lirik "He! yamko rambe yamko } \\
\text { aronawa kombe". Dengan ritme pada lirik } \\
\text { "Hey, not } 1 / 8 \text {, yamko rambe yamko not } \\
1 / 8 \text {, aronawa not } 1 / 8 \text {, kom not } 1 / 4 \text { dan be not } \\
1 / 2 \text { dengan titik ( } 3 \text { ketuk.). } \\
\text { Setelah melodi tema lagu pertama } \\
\text { dilanjutkan dnegan melodi jembatan pada } \\
\text { bar } 39 \text {, kemudian dilanjutkan dengan } \\
\text { pengulangan melodi } 1 \text { yang dibawakan } \\
\text { sopran dan alto pada bar } 40-43 \text {. } \\
\text { Dilanjutkan dengan melodi jembatan pada } \\
\text { bar } 44-49 \text { ketukan ke-2. }\end{array}$ & $\begin{array}{l}\text { Melodi tema lagu pertama } \\
\text { dibawakan oleh sopran dan alto, } \\
\text { dengan melodi " do sol sol la mi } \\
\text { sol la, sol sol la re mi do". dengan } \\
\text { lirik "He! yamko rambe yamko } \\
\text { aronawa kombe". Dengan ritme } \\
\text { pada lirik "Hey, not } 1 / 8 \text {, yamko } \\
\text { rambe yamko not } 1 / 8 \text {, arona not } \\
1 / 8 \text {, wa not } 1 / 2 \text { dengan titik ( } 3 \\
\text { ketuk), kom not } 1 / 4 \text { dan be not } 1 / 8 \text {. } \\
\text { Terdapat glissando sopran dan } \\
\text { alto kemudian dilanjutkan } \\
\text { pengulangan melodi } 1 \text { dimulai } \\
\text { dari bar } 17-20 \text {, dengan variasi } \\
\text { melodi pada lirik kombe. } \\
\text { Kemudian dilanjutkan melodi } \\
\text { jembatan pada bar } 28 \text {. }\end{array}$ \\
\hline 4. & Harmoni & $\begin{array}{l}\text { Harmoni tema lagu, I , IV , V , I. Harmoni } \\
\text { pada aransemen agustinus bambang jusana } \\
\text { hanya terbentuk berdasarkan akord pokok } \\
\text { dan balikan. Cenderung sederhana. }\end{array}$ & $\begin{array}{l}\text { Harmoni tema lagu yaitu I , IV , V } \\
\text {, I. banyak terbentuk variasi } \\
\text { harmoni baru seperti Akord } \\
\text { Bsus9 pada bar } 27 \text {. }\end{array}$ \\
\hline
\end{tabular}

Tabel 3. Komparasi Tema Lagu Bagian Kedua

\begin{tabular}{|c|c|c|c|}
\hline No. & $\begin{array}{c}\text { Indikator } \\
\text { Komparasi } \\
\text { Unsur Musik }\end{array}$ & $\begin{array}{c}\text { Aransemen Agustinus Bambang } \\
\text { Jusana }\end{array}$ & $\begin{array}{c}\text { Aransemen Budi Susanto } \\
\text { Yohanes }\end{array}$ \\
\hline 1. & Jumlah Bar & $\begin{array}{l}\text { Terdiri dari } 9 \text { bar mulai dari bar } 47 \\
\text { ketukan ke-3 - bar } 56 \text { ketukan pertama } \\
\text { down }\end{array}$ & $\begin{array}{l}\text { Terdiri dari } 16 \text { bar dimulai dari } \\
\text { bar } 29-44\end{array}$ \\
\hline 2. & Dinamika & Tidak terdapat dinamika. & $\begin{array}{l}\text { Terdapat banyak perubahan } \\
\text { dinamika, } \boldsymbol{m} \boldsymbol{f} \text { bar } 29, \boldsymbol{m} \boldsymbol{p} \text { bar } 33, \\
\boldsymbol{f} \text { bar } 37, \boldsymbol{m} \boldsymbol{p} \text { bar } 39 \text { dan } \\
\text { diminuendo. Berakhir dengan } \boldsymbol{p} \\
\text { pada bar } 44 .\end{array}$ \\
\hline 3. & $\begin{array}{l}\text { Melodi, Ritme dan } \\
\text { Lirik. }\end{array}$ & $\begin{array}{l}\text { Melodi tema lagu ke-2: Do sol sol sol la, } \\
\text { sol la sol la do re mi, re mi re mi do re mi } \\
\text { re do. dengan ritme not } 1 / 8,1 / 16 \text { dan not } \\
1 / 4 \text {. Dengan lrik " temino kiibe yumano } \\
\text { kobombeko yumano bungo awe ade" } \\
\text { dibawakan oleh sopran dan alto. Pada } \\
\text { melodi tema lagu ini masih sama dengan }\end{array}$ & $\begin{array}{l}\text { Melodi tema lagu ke-2 : Do sol sol } \\
\text { sol la, sol la sol la do re mi, re mi } \\
\text { re mi do re mi re do. melodi utama } \\
\text { sama dengan melodi pada } \\
\text { aransemen Budi susasanto } \\
\text { yohanes, namun terdapat } \\
\text { perbedaan pada ritme setelah lirik }\end{array}$ \\
\hline
\end{tabular}


Grenek: Jurnal Seni Musik Vol. 10 No. 1 (Juni 2021) Page: 82-92

Prodi Pendidikan Musik FBS Unimed

p- ISSN 2301-5349

e- ISSN 2579-8200

\begin{tabular}{|c|c|c|c|}
\hline & & $\begin{array}{l}\text { melodi dan ritme asli dari lagu Yamko } \\
\text { Rambe Yamko. kemudian terdapat } \\
\text { melodi jembatan pada bar } 52 \text { ketukan ke } \\
\text {-2. Dilanjutkan pengulangan melodi } \\
\text { pada bar } 53 \text { - } 56 \text { ketukan pertama down. }\end{array}$ & $\begin{array}{l}\text { "teminokibe" terdapat lirik rambe } \\
\text { dan rest } 1 \text { ketuk, sebagai pemisah. } \\
\text { Adapun melodi dibawakan secara } \\
\text { kanon dimulai dari tenor dan bass, } \\
\text { kemudian dilanjutkan sopran dan } \\
\text { alto. Kemudian terjadi } \\
\text { pengulangan melodi II dimulai } \\
\text { dari bar } 37 \text { - bar } 44 \text {. }\end{array}$ \\
\hline 4. & Harmoni & Harmoni tema lagu I,VI,V,III,IV,V,V,I & Harmoni tema lagu yaitu I,V,V,I \\
\hline
\end{tabular}

Tabel 4. Komparasi Bagian Tema Lagu Ke-3

\begin{tabular}{|c|c|c|c|}
\hline No. & $\begin{array}{c}\text { Indikator } \\
\text { Komparasi } \\
\text { Unsur Musik }\end{array}$ & $\begin{array}{c}\text { Aransemen Agustinus Bambang } \\
\text { Jusana }\end{array}$ & $\begin{array}{c}\text { Aransemen Budi Susanto } \\
\text { Yohanes }\end{array}$ \\
\hline 1. & $\begin{array}{l}\text { Nada dasar dan } \\
\text { Tangga nada }\end{array}$ & F Mayor & E Mayor \\
\hline 2. & Birama & $4 / 4$ & $\begin{array}{l}\text { 4/4 dan terdapat perubahan birama } \\
\text { pada bar } 86 \text { menjadi } 6 / 4\end{array}$ \\
\hline 3. & Tempo & Allegro $=130 \mathrm{MM}$ (cepat) & Vivace $=112 \mathrm{MM}($ lincah $)$ \\
\hline 4. & Jumlah Bar & $\begin{array}{l}\text { Terdiri dari } 5 \text { bar dimulai dari bar } 56 \\
\text { ketukan ke-3 up - bar } 60 \text {. }\end{array}$ & $\begin{array}{l}\text { Terdiri dari } 12 \text { bar, dimulai dari bar } \\
75 \text { ketukan ke- } 3 \text { up - bar } 86\end{array}$ \\
\hline 5. & Dinamika & mengikuti dinamika sebelumnya. & $\begin{array}{l}\text { bar 78sopran } \boldsymbol{m} \boldsymbol{f} \text {, dan alto } \boldsymbol{f} \\
\text { kemudian bar } 82 \text { terdapat } \\
\text { dinamika } \boldsymbol{f} \text { pada solo sopran dan } \\
\text { solo tenor. }\end{array}$ \\
\hline 6. & $\begin{array}{ll}\text { Melodi, } & \text { Ritme } \\
\text { dan Lirik. } & \end{array}$ & $\begin{array}{l}\text { "sol sol sol la, sol sol re sol, do do re mi re } \\
\text { mi sol la do do" dengan ritme not } 1 / 8,1 / 4 \\
1 / 2 \text {, triol dan diakhiri not } 3 \text { ketuk . } \\
\text { dengan lirik "Hongke-hongke, hongke } \\
\text { riro, hongke jambe, jambe jambe riro yang } \\
\text { dibawakan oleh sopran. (pada bagian } \\
\text { tema lagu ke-3 melodi dan ritme asli dari } \\
\text { lagu yamko rambe yamko dirubah) }\end{array}$ & $\begin{array}{l}\text { "sol sol sol la, sol sol la re, do do re } \\
\text { mi, re re mi do" dengan ritme not } \\
1 / 8,1 / 2 \text {. Tidak ada triol pada melodi } \\
\text { ke-3. dengan lirik "Hongke- } \\
\text { hongke, honke riro, hongke jambe, } \\
\text { jambe jambe riro yang dibawakan } \\
\text { oleh sopran. Kemudian terdapat } \\
\text { melodi solo sopran dan solo tenor } \\
\text { pada bar } 82 \text { ketukan ke-3 up. } \\
\text { Kemudian terjadi pengulangan } \\
\text { melodi } 3 \text { pada bar } 82 \text { ketukan ke-3 } \\
\text { up - bar } 86 \text {. }\end{array}$ \\
\hline 7. & Harmoni & $\mathrm{IV}, \mathrm{V}, \mathrm{V}, \mathrm{I}$ & IV $, \mathrm{V}, \mathrm{V}, \mathrm{I}$ \\
\hline
\end{tabular}

Tabel 5. Komparasi Bagian Penutup

\begin{tabular}{|l|l|l|l|}
\hline No. & \multicolumn{1}{|c|}{$\begin{array}{c}\text { Indikator } \\
\text { Komparasi } \\
\text { Unsur Musik }\end{array}$} & \multicolumn{1}{|c|}{$\begin{array}{c}\text { Aransemen Agustinus Bambang } \\
\text { Jusana }\end{array}$} & \multicolumn{1}{c|}{$\begin{array}{c}\text { Aransemen Budi Susanto } \\
\text { Yohanes }\end{array}$} \\
\hline 1. & Jumlah Bar & 6 bar ( dimulai dari bar 75-80) & 9 bar ( dimulai dari 86 -94) \\
\hline 2. & Dinamika & $\begin{array}{l}\text { Cresscendo pada bar 80 sebagai } \\
\text { puncak klimaks lagu. }\end{array}$ & $\begin{array}{l}\text { Bar 89 -93 } \text { } \text {, dan Cresscendo pada } \\
\text { bar 93 ketukan 2 up dan berakhir ff } \\
\text { pada bar 94. }\end{array}$ \\
\hline 3. & $\begin{array}{l}\text { Melodi, Ritme dan } \\
\text { Lirik. }\end{array}$ & $\begin{array}{l}\text { Melodi penutup : "do sol la sol sol, mi } \\
\text { re mi sol sol" dan "do sol la sol sol, mi } \\
\text { sol la sol la do do" dengan ritme not 1/8, }\end{array}$ & $\begin{array}{l}\text { Melodi dimulai oleh tenor dan bass, } \\
\text { kemudian bar 88 alto 1 masuk } \\
\text { sebagai pembawa melodi, bar 90 }\end{array}$ \\
\hline
\end{tabular}




\begin{tabular}{|l|l|l|l|}
\hline & $\begin{array}{l}1 / 16,1 / 4 \text { dan 1/2 dan diakhiri fermata } \\
\text { pada bar 80, dengan lirik "hey yamko } \\
\text { rambe, hey yamko rambe, yamko } \\
\text { rambe, hey yamko rambe yamko" } \\
\text { ditutup dengan shout "hey". Melodi } \\
\text { dinyanyikan secara tutti pada bar 75. }\end{array}$ & $\begin{array}{l}\text { sopran 1 dan 2 masuk membawa } \\
\text { melodi dengan melodi sopran 1 "mi } \\
\text { do re la do re" dan sopran 2 "do sol } \\
\text { sol la mi sol la" Pada bar 90 - 93 alto } \\
\text { tenor dan bass terjadi pengulangan } \\
\text { yang sama dengan bar 89 dengan } \\
\text { ritme dan nada yang melodi yang } \\
\text { sama ditutup dengan sopran dan alto } \\
\text { serta lirk "he" dengan aksen pada } \\
\text { bar 94. }\end{array}$ \\
\hline 4. & Harmoni & $\begin{array}{l}\text { I, IV, I, IV, I dan ending, I, IV , V dan } \\
\text { bembentuk harmoni akord Esus9 } \\
\text { hingga akhir lagu. }\end{array}$ \\
\hline
\end{tabular}

Tabel 6. Komparasi Introduksi lagu Yamko Rambe Yamko Aransemen Agustinus Bambang Jusana dengan Budi Susanto Yohanes.

\begin{tabular}{|c|c|c|c|}
\hline No & $\begin{array}{l}\text { Indikator } \\
\text { Komparasi }\end{array}$ & Aransemen Agustinus Bambang Jusana & $\begin{array}{c}\text { Aransemen Budi Susanto } \\
\text { Yohanes }\end{array}$ \\
\hline 1. & Unsur Musik. & $\begin{array}{l}\text { Menggunakan nada dasar F Mayor, } \\
\text { tempo Allegro }=130 \mathrm{MM} \text {, Birama } 4 / 4 \text {. } \\
\text { Menggunakan dinanika } f \text { dari bar } 1-10 \\
\text { yang }\end{array}$ & $\begin{array}{l}\text { Menggunakan nada dari E Mayor, } \\
\text { tempo Vivace }=112 \mathrm{MM} \text {, Birama } \\
\text { 4/4. terdapat banyak perubahan } \\
\text { dinamika }\end{array}$ \\
\hline & & $\begin{array}{l}\text { embuat aransemen terkesan dibuka dengan } \\
\text { megah. Serta terdapat perubahan biarama } \\
\text { pada bar } 11 \text { menjadi fp dan decrescendo. } \\
\text { - Terdiri dari } 35 \text { bar dengan } 3 \text { Bagian } \\
\text { - Melodi didominasi dengan lirik } \\
\text { menggunakan huruf vokal E,O dan A. } \\
\text { diawali dengan unisono dengan notasi } \\
\text { "do sol la sol mi mi re do re do do" yang } \\
\text { diakhiri dengan fermata. Terdapat bagian } \\
\text { solo tenor dengan melodi do sol la mi } \\
\text { sol, do sol la do do" yang diikuti secara } \\
\text { kanon oleh suara lainnya, bagian solo } \\
\text { tenor pada introduksi merupakan salah } \\
\text { satu identitas dari aramsemen Agustinus } \\
\text { Bambang Jusana. } \\
\text { Bagian akhir terdapat Recitativo dimana } \\
\text { terdapat teriakan khas masyarakat Papua } \\
\text { yang menepuk-nepuk mulut sambil } \\
\text { mengeluarkan suara atau bersorak "wuu" } \\
\text { yang dilakukan secara tutti ( semua } \\
\text { suara melakukan hal yang sama) dan } \\
\text { secara kanon (bersahutan) dan diakhiri } \\
\text { dengan teriakan "hey" dilakukan } \\
\text { secaramouth patting menepuk-nepuk } \\
\text { mulut sambil mengeluarkan suara atau } \\
\text { bersorak "wuu" yang dilakukan secara } \\
\text { tutti ( semua suara melakukan hal yang }\end{array}$ & $\begin{array}{l}\text {, bar } 1 \text { mfdengan marcato artinya } \\
\text { seperti berbicara, kemudian subito } \\
\text { ppada bar } 2 \text {, bar } 3 \text { kembali ke } \boldsymbol{m f} \text {, } \\
\text { bar } 4 \text { cresscendo fortedan bar } 5 \boldsymbol{p} \\
\text { dengan marcato, dan bar } 10 \\
\text { menjadi crescendodan bar } 13 \\
\text { diakhiri dengan } \text { cresscendo forte. } \\
\text { - } \text { Terdiri dari } 12 \text { bar dengan } 1 \\
\text { Bagian ( lebih singkat) } \\
\text { - didominasi dengan lirik "he } \\
\text { yamko rambe" yang dibawakan } \\
\text { oleh suara tenor dan bass secara } \\
\text { berulang-ulang yang } \\
\text { membentuk harmonisasi akord } \\
\text { Esus6,9, serta dengan } \\
\text { perubahan dinamika secara } \\
\text { bertahap, dimulai dari } \text { mf, } \boldsymbol{p}, \\
\text { dan } \text { crescendoforte, kemudian } \\
\text { terdapat pengulangan } \\
\text { dibawakan sopran dan alto, } \\
\text { kemudian disambut tenor dan } \\
\text { bass sehingga melengkapi } \\
\text { harmoni yang membentuk } \\
\text { akord Esus6,9., dan diakhiri } \\
\text { dengan lirik "he yamko rambe } \\
\text { yamko" dengan ritme yang } \\
\text { sama dan ditutup dengan } \\
\text { teriakan "hey" dengan aksen, }\end{array}$ \\
\hline
\end{tabular}


Grenek: Jurnal Seni Musik Vol. 10 No. 1 (Juni 2021) Page: 82-92

Prodi Pendidikan Musik FBS Unimed

p- ISSN 2301-5349

e- ISSN 2579-8200

\begin{tabular}{|c|c|c|c|}
\hline & & $\begin{array}{l}\text { sama) dan secara kanon (bersahutan) dan } \\
\text { diakhiri dengan } \\
\text { eriakan "hey" }\end{array}$ & $\begin{array}{l}\text { glissandodengan crescendo } \\
\text { forte, }\end{array}$ \\
\hline 2. & Karakteristik & $\begin{array}{l}\text { - Introduksi berdurasi panjang dan terdiri } \\
\text { dari } 3 \text { bagian. } \\
\text { - Terkesan lebih megah dikarenakan } \\
\text { penggunaan unisono dengan dinamika } \\
\text { forte } \\
\text { - Identik dengan melodi awal yaitu, do sol la } \\
\text { sol, mi mi re do re do do, dengan lirik } \\
\text { yang didominasi huruf vokal E,O dan A } \\
\text { yang merupakan karakteristik vokal tradisi } \\
\text { masyarakat Papua. } \\
\text { - Menonjolkan karakteristik tradisi } \\
\text { masyarakat Papua, seperti adanya } \\
\text { recitativo ( teriakan khas mayarakat } \\
\text { Papua) dengan caramouth patting dan } \\
\text { menonjolkan karakteristik vokal yang } \\
\text { dibentuk oleh meodi solo tenor yang } \\
\text { diikuti posisi suara lainnya. }\end{array}$ & $\begin{array}{l}\text { - Introduksi berdurasi singkat } \\
\text { hanya terdiri dari } 1 \text { bagian. } \\
\text { - Hanya terdiri dari repitisi atau } \\
\text { pengulangan melodi yang } \\
\text { membentuk harmoni. } \\
\text { - Banyak perubahan dinamika. } \\
\text { - Bagian awal cenderung } \\
\text { menonjolkan penggunaan } \\
\text { harmonisasi yang membentuk } \\
\text { akord Esus } 9,6 \text { yang dibentuk } \\
\text { secara vertikal. }\end{array}$ \\
\hline
\end{tabular}

\section{SIMPULAN}

Berdasarkan hasil penelitian yang telah dilakukan di Laboratorium Sendratasik Fakultas Bahasa dan Seni, Universitas Negeri Medan tentang Komparasi Lagu Yamko Rambe Yamko karya Agustinus Bambang Jusana dengan Budi Sutanto Yohanes, maka penulis mengambil beberapa kesimpulan sebagai berikut.

Unsur musik pada kedua aransemen memiliki perbedaan dimulai dari perbedaan nada dasar dan tempo, lagu Yamko Rambe Yamko aransemen Agustinus Bambang Jusana menggunakan nada dasar F Mayor dengan tempo Aleggro $=130 \mathrm{MM}$, sementara aransemen Budi Susanto Yohanes menggunakan nada dasar E Mayor dengan tempo vivace $=112 \mathrm{MM}$. Melodi, ritme dan lirik dari kedua aransemen pada bagian tema pada umumnya sama dengan melodi asli dari lagu Yamko Rambe Yamko, tetapi terdapat beberapa perbedaan dimana pada aransemen Agustinus Bambang Jusana terjadi perubahan tanda birama pada bagian tema lagu yang kedua. Selain itu, melodi dan ritme dari kedua aransemen memiliki perbedaan baik pada bagian introduksi, tema, variasi tema, dan penutup. Jumlah bar dari kedua aransemen juga berbeda, aransemen Agustinus Bambang Jusana terdiri dari 80 bar, sedangkan aransemen Budi Susanto Yohanes terdiri dari 94 bar. Harmoni dari kedua aransemen pada bagian tema lagu pada umumnnya sama yaitu membentuk akord pokok I, IV, V, dan I pada aransemen Agsutinus Bambang Jusana, harmoni disusun berdasarkan akord pokok namun hanya berbeda wilayah nada atau mebentuk akord balikan, sementara pada aransemen Budi Susanto Yohanes, harmoni cenderung lebih bervariasi dimana banyak pengunaan akord Sus, Maj7, dan akord variasi lainnya sehingga aransemen ini identik dengan harmonisasi yang disusun dari setiap posisi suaranya. Dinamika yang digunakan pada kedua aransamen yaitu, $p, m p, m f, f, f p$, ff, crescendo, descrescendo, 
Grenek: Jurnal Seni Musik Vol. 10 No. 1 (Juni 2021) Page: 82-92

Prodi Pendidikan Musik FBS Unimed

p- ISSN 2301-5349

e- ISSN 2579-8200

dan diminuendo. Pada aransemen Budi Susanto Yohanes lebih banyak terdapat perubahan tanda dinamika dibandingkan dengan aransemen Agustinus Bambang Jusana.

Bagian introduksi dari kedua aransemen memilki perbedaan dimana pada aransemen Agustinus Bambang Jusana, bagian introduksi didominasi oleh teriakan peperangan khas masyarakat papua yang menggunakan vokal E,O,A serta melakukan mouthpatting (menepuk mulut sambil berteriak), dan identik dengan melodi solo tenor yang menjadi lead vocal dan diikuti secara unisono oleh posisi suara lainnya, terlihat bahwa bagian introduksi aransemen Agustinus Bambang Jusana sangat menonjolkan karakteristik dan identitas tradisi masyarakat Papua. Sedangkan aransemen Budi Susanto Yohanes bagian introduksi cenderung lebih singkat dan didominasi oleh penggunaan harmonisasi yang bervariatif yang disusun secara kanon / bersahutan dari setiap posisi suara.

\section{DAFTAR PUSTAKA}

Anderson, W.R. 1978. The Musical Companion.New York, Harcourt Brace Jovanovich.

Arikunto, Suharsimi.2017 Prosedur Penelitian (Suatu Pendekatan Praktik) Jakarta :Penerbit Rineka Cipta

Banoe, Pono. 2003. Kamus Musik. Yogyakarta :Penerbit Kanisinus

Boone, Brian and Marc Schonbrun. 2017. Music Theory From Keys and Scales To Rhytm and Melody, An Essential Primer on The Basics of Music Theory. Ebook .Adams Media. New York. (Online) http://www.pdfdrive.com/musictheory

Budidharma, Pra. 2001. PengantarKomposisi dan Aransemen, Jakarta: PT. Elex Media Komputindo

Budilinggono, I. 1993. Bentuk dan Analisis Musik. Jakarta: Departemen Pendididkan dan Kebudayaan https://iopscience.iop.org/article/10.1088/1755-1315/343/1/012208/pdf

Edmund Prier SJ, Karl. 2009. Ilmu Bentuk Musik .Yogyakarta :Pusat Musik Liturgi.2015. IlmuBentukMusik. Yogyakarta :Pusat Musik Liturgi

Eka Panca, Yohanes. 2020. Komparasi Aransemen Lagu Janger Karya Budi Susanto Yohanes Dengan AvipPriatna / Agustinus Bambang Jusana.Skripsi Universitas Negeri Medan.

Firmansyah, Feri. 2015. Bentuk dan Struktur Musik Batang hari Sembilan. Jurnal Ekspresi Seni Vol. Instititut Seni Padang Panjang.

https://www.bbc.com/indonesia/indonesia-53285500 (Online) diakses pada tanggal 8 Oktober 2020, pukul 17:00 WIB.

https://kbbi.web.id/simbol(Online) diakses pada tanggal 8 Oktober 2020, pukul 17:00 WIB.

http://www.google.com/gambar+jangkauan +suara+manusia,diakses pada tanggal 8 Oktober 2020, pukul 17:00 WIB.

Hurds, Michael. 1979. The Oxford Ilustrated Dictionary Of, Music, Second Edition. 
Grenek: Jurnal Seni Musik Vol. 10 No. 1 (Juni 2021) Page: 82-92

Prodi Pendidikan Musik FBS Unimed

p- ISSN 2301-5349

e- ISSN 2579-8200

Melbourne. Oxford University Press.

Isbah, Faliqul dan Joko Wiyoso. 2019. Komposisi dan Aransemen Musik Babablu

Sebagai Sebuah Kajian Musikalitas Tradisional. Jurnal Seni Musik

Universitas Negeri Semarang. (Online),

http://journal.unnes.ac.id/siu/index.php/jsm

Kodijat Marzoeki , Latifah . 2004. Istilah - istilah Musik. Jakarta :Djambatan

McFarlane, Stuart dkk. 2020. Alarm Tones, Music and Their Elements: Analysis of

Reported Waking Sounds to Counteract Sleep Inertia. Plos One

Journal.School of Media and Communication.RMIT University,

Meoulbourne, Australia.

(Online)http://doi.org/10.1371/journal.pone.0215788.

Medica, Reyhan Swarna. 2018. Aransemen Agustinus Bambang Jusana

Lagu Yamko Rambe Yamko Untuk Paduan Suara.Skripsi Universitas

Pendidikan Indonesia Bandung.(Online) http://repository.upi.edu/45884/ pada tanggal 28 Agustus 2020.

Miller, Michael. 2002. The Complete Idiot's Guide to Music Theory. United States Of America : Alpha

Muttaqin, Moh. 2008. Seni Musik Klasik Jilid I.Jakarta :Direktorat Pembinaan Sekolah Menengah Kejuruan.

Nallin, Walter. 1968. The Musical Idea (A Consideration Of Music And Its Way. NewYork. The MACMillan Company

Sarrazin, Natalie Phd, 2015. Music And The Child. SUNY Libraries and Suny Press.

E-Book (Online) http://milnepublishing.geneseo.edu/music-and-the child/front-matter/about/

Siegmaster, Elie. 1985. Harmony And Melody. California: Wadworth Publishing

Simanungkalit, N. 2008.Teknik Vokal Paduan Suara. Jakarta: Gramedia Pustaka Utama

Suroso, Panji, Mukhlis Habullah, dan Ifwanul Hakim. 2019. Dasar Dasar Analisis Bentuk Musik. Medan : CV. Kenangan Emas.

Teie, David. 2016. A Comparative Analysis of The Universal Elements of Music and The Fetal Environment. Hypotesis and Theory. Frontiers in Phsycology.(Online)

https://www.researchgate.net/publication/306001632_A_Comparative_Analy sis_of the Universal_Elements_of_Music_and the Fetal_Environment. 